J. Clin. Chem. Clin. Biochem.

Vol. 25, 1987, pp. 699-703

(C) 1987 Walter de Gruyter \& Co. Berlin - New York

\title{
Initial Results with a Commercial Luminescence Enhanced Enzyme Immunoassay for the Determination of Carcinoembryonic Antigen (CEA) in Body Fluids
}

\author{
By W. G. Wood \\ Klinische Laboratorien, Klinik für Innere Medizin (Direktor Prof. Dr. P. C. Scriba), Medizinische Universität \\ zu Lübeck
}

(Received September 16, 1986//February 13/July 30, 1987)

Summary: A commercially available luminescence enhanced enzyme immunoassay (Amerlite - Amersham International) for carcinoembryonic antigen (CEA) was compared with an established enzyme immunoassay (Monoclonal 1-step Assay - Abbott Laboratories). A reference range for healthy blood donors $(\mathrm{n}=272)$ was established for both kits. The blood donors were not separated into smokers and non-smokers, but were excluded from the reference group if they showed abnormal aminotransferase or $\gamma$-glutamyltranspeptidase serum values. Twenty eight donors were excluded in this way. The test group consisted of 130 known tumour patients, and included pre- and post-operative serum samples. Normal and elevated CEA values were present. All sera were negative for $\mathrm{HBsAg}$, anti-HBsAg and anti-HIV as determined with commercial enzyme immunoassays used routinely in the blood bank.

The luminescence enhanced immunoassay gave rise to a reference range (95\% confidence limits) of less than $3.91 \mu \mathrm{g} / \mathrm{l}$ in comparison with the enzyme immunoassay, which had a reference range of less than $4.12 \mu \mathrm{g} / 1$. The proportion of elevated values in the tumour patient group was $37 / 130$ for the luminescence enhanced enzyme immunoassay and $28 / 130$ for the enzyme immunoassay.

The correlation of values from both methods in the blood donor group was good $(r=0.771, n=272)$. The CEA levels found in the tumour patient group differed significantly when measured in both kits (Wilcoxon matched-pair signed rank test $-\mathrm{c}$-alpha $=-6.52, \mathrm{p}<0.01, \mathrm{n}=130$ ), the Amersham kit giving the higher results (median valuiues - Abbott $2.35 \mu \mathrm{g} / \mathrm{l}$, Amersham $2.50 \mu \mathrm{g} / \mathrm{l}$ ).

Although the CEA concentrations in the blood donor group were similar for both kits (median values Abbott $1.12 \mu \mathrm{g} / \mathrm{l}$, Amersham $0.92 \mu \mathrm{g} / \mathrm{l}$ ), the Abbott kit gave significantly higher results statistically (Wilcoxon matched-pair signed rank test - c-alpha $=-3.55, \mathrm{p}<0.01, \mathrm{n}=272$ ).

From dilution studies, the lower limit of detection for both assays was set at $0.25 \mu \mathrm{g} / \mathrm{l} \mathrm{CEA}$ in serum, all values below this being given as not detectable.

As in the case of manyy other kits, the standards could not be interchanged, although both were calibrated against the international reference preparation WHO 73/601.

The luminescence enhanced enzyme immunoassay can be included in the list of non-isotopic immunoassays for CEA, although, like its competitors, it can only be used in the follow-up of tumour patients, and not as a screening test. 


\section{Introduction}

Although the first immunoassays using luminescent labels were published over a decade ago (1), the commercial exploitation of these methods has only recently led to the production of immunoassay kits using luminescent detection.

This brief communication reports the preliminary performance of a luminescence enhanced enzyme immunoassay for the determination of carcinoembryonic antigen (CEA). The method used for the routine CEA determination, an enzyme immunoassay, was used as a comparison (2).

Serum samples were obtained from healthy blood donors and from known tumour-bearers.

Horseradish peroxidase was used as label in both cases, the enzyme immunoassay using $o$-phenylene diamine as chromogen, the luminescence enhanced immunoassay having an aryl hydrazide and an enhancer as luminogen. In both cases, the peroxidase functioned as an enzyme, the signal being proportional to the amount of enzyme bound to the antigenantibody complex, i.e. to the amount of nascent oxygen produced. This is in contrast to "conventional" chemiluminescence immunoassays using aryl hydrazide labels, where the hydrogen peroxide is in excess, and the amount of immobilised luminogen determines the light output (3).

\section{Materials and Methods}

Apparatus and Kits

The enzyme immunoassay was purchased from Abbott Diagnostics (Wiesbaden Delkenheim, D) and was the monoclonal 1-step CEA-EIA kit. The assay was performed manually and was measured in a microprocessor-controlled spectrophotometer (Quantum I - Abbott).

The luminescence enhanced immunoassay, supplied by Amersham Buchler (Braunschweig, D), was the Amerlite CEA monoclonal antibody assay. Pipetting of samples was performed manually, other steps being performed automatically. The Amerlite system was a closed system as far as measurement and data-processing were concerned. At the time of writing, laboratory-own assays could not be performed using the system.

The Abbott kit used the familiar ball and tray system, while the Amerlite kit used coated well-strips which were fitted into microtitre plates.

\section{Samples}

Blood donors were chosen as the reference group, excluding those who had abnormal aminotransferase and $\gamma$ glutamyltranspeptidase values. All were negative for $\mathrm{HBsAg}$, anti $\mathrm{HBsAg}$ and anti $\mathrm{HIV}$, as determined by modern enzyme immunoassays. Twenty eight out of 300 blood donors were excluded from the study as a result of the above screening procedure. No discrimination was made between smokers and non-smokers.
Serum from tumour patients was taken before and after operation, no discrimination being made in the 130 patients studied. The sera included normal and clevated CEA concentrations.

\section{Statistics}

Non-parametric statistics were used throughout, as the distribution of data in both groups was non-Gaussian. Tests used included the Mann-Whitney U-test ' with z-transformation and the Wilcoxon signed rank test for matched pairs with c-alpha calculation. The confidence limits for each group were given as the relevant percentile together with the median value. The ratio mean/median was used as an index of the data distribution. In all cases, the enzyme immunoassay (Abbott) was entered as $\mathrm{x}$, the luminescence enhanced enzyme immunoassay (Amersham) as $y$.

\section{Results}

The assay schemes are shown in tables $1 \mathrm{a}$ and $1 \mathrm{~b}$. The distribution of serum concentrations in 272 healthy blood donors are shown in table $2 \mathrm{a}$, those for the 130 tumour patients in table $2 \mathrm{~b}$. Table $2 \mathrm{c}$ shows the correlation between both groups. Relevant quality control parameters are given in table 3 . The light index values of the standard curve from the luminescence enhānced enzyme immunoassay are shown in table $4 \mathrm{a}$. (The light index values of the samples reflect the light intensity of the peroxidaseluminogen mixture in each well. They act as a quality control parameter inasmuch as when they lie outside a defined region, the latter being given by the producer, accuracy and precision can no longer be guaranteed.) Although the light intensity decreases with time, due to the depletion of substrate and/or inactivation of the peroxidase, the values read off the standard curve were stable over 60 minutes after addition of the signal reagent, even though the printout showed the flag "poor curve" when the light index fell below the lower limit of acceptance, which in this case was 3.0. These results are summarised in table $4 \mathrm{~b}$. Concurrence of values of samples measured in both kits are shown for the 130 tumour patients in table 5. Table 6 a shows the effect of diluting the first standard with the zero standard to attempt to define the lower detection limit of each assay. In the case of the Amerlite assay, this was non-linear. Table $6 \mathrm{~b}$ shows the effect of measuring the standards and control sera from one kit as samples in the contralateral kit. Table $6 \mathrm{c}$ shows the results of diluting the Amersham $3 \mu \mathrm{g} / 1$ standard with a serum which repeatedly gave an undectable value in the Abbott assay. After correcting the 1:2 dilution for an "exogenous CEA" of $0.04 \mu \mathrm{g} / \mathrm{l}$, the expected values for the serial dilution were obtained down to ca. $0.2 \mu \mathrm{g} / 1$. The lower limits of detection were set at $0.25 \mu \mathrm{g} / 1$, all values below this being reccorded as not detectable. 
Tab. 1 a. Assay scheme for the Abbott CEA-EIA monoclonal (1-step) enzyme immunoassay kit.

$50 \mu \mathrm{ll}$ sample/standard

$200 \mu$ anti-CEA peroxidase conjugate

1 anti-CEA coated ball

Incubate $60 \mathrm{~min}$ at $45^{\circ} \mathrm{C}$

Wash with $2 \times 5 \mathrm{ml}$ water

Transfer beads to $75 \times 12 \mathrm{~mm}$ test tubes

Add $300 \mu \mathrm{l} o$-phenylene diamine solution

Incubate $30 \mathrm{~min}$ at ambient temperature

Add $1 \mathrm{ml} 1 \mathrm{~mol} / 1$ sulphuric acid, vortex and measure at $492 \mathrm{~nm}$.

Tab. 1 b. Assay scheme for Amersham Amerlite CEA assay (monoclonal) assay kit.

$100 \mu \mathrm{l}$ assay reagent

$100 \mu \mathrm{l} \mathrm{sample/standard}$

Incubate $120 \mathrm{~min}$ at $37^{\circ} \mathrm{C}$

Wash on Amerlite washer

$200 \mu l$ conjugate reagent (anti-peroxidase)

Incubate and wash as above

$250 \mu$ l signal reagent

Read off in Amerlite analyser $2-20$ min after signal reagent addition

\section{Discussion}

The combination of an enzyme label and luminogen as signal has been described for both dehydrogenases (4) and for peroxidases $(1,5)$. The enhancement and stabilisation of the light signal is system-specific and cannot be transferred to other systems, even when these use the same components in a different assay form (3).

The enhancement and stabilising systems have been patented (5) as far as the peroxidase/acyl-aryl hydrazide system is concerned. As the peroxidase used in the Amerlite kit serves as an enzyme, and not as a "one-off" catalyst as in the conventional chemiluminescence assay (6), the light signal depends upon the activity of the enzyme. The light signal can be enhanced by addition of compounds such as 4-iodophenol and $D$-luciferin (5).

Tables $4 \mathrm{a}$ and $4 \mathrm{~b}$ show that although the light intensity decreases with time, useable standard curves are produced, even for times well in excess of those given by the manufacturer between addition of signal reagent and measurement.

The values from both kits correlate well with each other, as can be seen in tables $2 a-2 c$, although aberrant values can occur (tab. 5) in which one kit
Tab. 2a. Distribution of CEA values in serum from 272 bealthy blood donors.

\begin{tabular}{lll}
\hline Parameter & Abbott EIA & Amersham LEIA \\
\hline 2.5 Percentile & n. d. & n. d. \\
16 Percentile & $0.22 \mu \mathrm{g} / \mathrm{l}$ & n.d. \\
Median $(50$ percentile $)$ & 1.12 & $0.92 \mu \mathrm{g} / 1$ \\
84 Percentile & 2.50 & 2.28 \\
97.5 Percentile & 4.12 & 3.91 \\
mean & $1.40 \mu \mathrm{g} / \mathrm{l}$ & $1.31 \mu \mathrm{g} / 1$ \\
mean/median & 1.25 & 1.42 \\
\hline
\end{tabular}

Tab. 2 b. Distribution of CEA serum levels in 130 tumour patients.

\begin{tabular}{lll}
\hline Parameter & Abbott EIA & Amersham LEIA \\
\hline 2.5 Percentile & n.d. & $0.32 \mu \mathrm{g} / \mathrm{l}$ \\
16 Perdentile & n. $\mathrm{d}$. & 1.10 \\
Median $(50$ percentile) & $2.35 \mu \mathrm{g} / 1$ & 2.50 \\
84 Percentile & 5.87 & 5.56 \\
97.5 Percentile & 41.4 & 38.4 \\
mean & 11.2 & 11.5 \\
mean/median & 4.78 & 4.57 \\
\hline
\end{tabular}

Tab. 2c. Correlation data for the blood donors $-x$-values $=$ Abbott, $y$-values $=$ Amersham. Regression line $y=$ $a+b x$ and $x=a+b y$.

$\mathrm{r}=0.771, \mathrm{n}=272$

$\mathrm{a}_{\mathrm{yx}}=0.108, \mathrm{~b}_{\mathrm{yx}}=0.888$

$a_{x y}=0.493, b_{x y}=0.670$

Wilcoxon signed rank test (Abbott vs Amersham)

Blood donors - c-Alpha $=-3.55, \mathrm{n}=254$ (18 pairs discarded - no rank difference) $p<0.01$

Tumour patients - c-Alpha $=+6.45, \mathrm{n}=123$ (7 pairs discarded - no rank difference) $p<0.01$

key:

n.d. - under detection limit

EIA - enzyme immunoassay, LEIA - Luminescence enhanced enzyme immunoassay.

gives values inside the established reference range, whereas the other one gives elevated values. Statistically speaking, the results from both kits differed significantly, which was reflected for example by the difference in the reference ranges.

Both kit protocols contained tables of expected values for healthy and ill patients. For the Amersham kit, data provided on 300 blood donors, including smokers and non-smokers, showed that $98.6 \%$ had values under $5.0 \mu \mathrm{g} / \mathrm{l}$. This coincides well with the values found in this study $(98.4 \%$ of values less than $5 \mu \mathrm{g} / \mathrm{l})$. 
Tab. 3. Intra- and interassay quality control data.

\section{Intra-assay data.}

Abbotl EIA - mean coefficient of variation from compound precision profiles from 30 assays $(n=527$ data pairs, concentration range $0.3-10 \mu \mathrm{g} / \mathrm{l})=5.75 \%$.

Amersham LEIA - mean coefficient of variation from compound precision profiles from 20 assays $(n=344$ data pairs, concentration range $0.3-10 \mu \mathrm{g} / \mathrm{l})=2.97 \%$.

Interassay data

\begin{tabular}{lll}
\hline Parameter & Abbott & Amersham \\
\hline Serum 1 mean & $2.24 \mu \mathrm{g} / 1$ & $2.81 \mu \mathrm{g} / 1$ \\
CV & $7.14 \%$ & $4.84 \%$ \\
n & 30 & 20 \\
Serum 2 mean & $9.84 \mu \mathrm{g} / 1$ & $10.9 \mu \mathrm{g} / 1$ \\
CV & $5.89 \%$ & $4.30 \%$ \\
n & 30 & 20 \\
Serum 3 mean & $44.6 \mu \mathrm{g} / 1$ & $42.0 \mu \mathrm{g} / 1$ \\
CV & $5.77 \%$ & $4.33 \%$ \\
n & 30 & 20
\end{tabular}

For details about precision profiles - see I.c. (2)

Tab. 4 a. Light index values of the Amersham LEIA for the standard curve. Time interval from signal reagent addition 2-60 minutes.

\begin{tabular}{llllll}
\hline $\begin{array}{l}\text { Standard } \\
\mu \mathrm{g} / 1\end{array}$ & \multicolumn{5}{l}{ Signal } \\
\cline { 2 - 6 } & $2 \mathrm{~min}$ & $5 \mathrm{~min}$ & $20 \mathrm{~min}$ & $40 \mathrm{~min}$ & $60 \mathrm{~min}$ \\
\hline 0 & 0.038 & 0.039 & 0.034 & 0.026 & 0.025 \\
3 & 0.194 & 0.204 & 0.168 & 0.084 & 0.054 \\
6 & 0.500 & 0.520 & 0.419 & 0.237 & 0.145 \\
12 & 0.778 & 0.780 & 0.641 & 0.399 & 0.244 \\
25 & 2.18 & 2.17 & 1.77 & 1.24 & 0.784 \\
60 & 4.32 & 4.26 & 3.51 & 2.60 & 1.68 \\
Light index & 4.34 & 4.35 & 3.57 & 2.61 & 1.69 \\
\hline
\end{tabular}

The 40 and 60 minute read-outs gave the flag "poor curve" as a warning, as the light-index fell under the limit set in the programme (here for CEA 3.00)

Tab. 4 b. Correlation of the CEA-values compared with the 5minute values.

$n=84$ wells in each case, 5 min values as $x$

5 vs $20 \min -$

$r=0.999, a_{y x}=-0.259, b_{y x}=1.02, a_{x y}=0.259, b_{x y}=0.979$

5 vs $40 \mathrm{~min}-$

$r=0.999, a_{y x}=-0.324, b_{x y}=1.03, a_{x y}=0.324, b_{x y}=0.965$

5 vs $60 \mathrm{~min}-$

$r=0.999, a_{y x}=-0.338, b_{y x}=1.03, a_{x y}=0.339, b_{x y}=0.969$

The values were statistically significant in each case $(p<0.001)$ but this had no clinical implications and showed that differences were due to curve fitting and not to individual differences in the signals from each well.
Tab. 5. Concurrence of values in the tumour patient sera as evaluated by both assays, using the reference ranges established in tab. 2 a.

Abbott normal, Amersham normal 87

Abbott elevated, Amersham normal

6

Abbott normal, Amersham elevated

15

Abbott elevated, Amersham elevated

22

Discrepancies occurred in $17 \%$ of the sera tested.

Tab. 6 a. Dilution of the first standard with the zero standard to define the lower limit of detection of the assay.

\begin{tabular}{llll}
\hline & $\begin{array}{l}\text { Expected } \\
\text { value } \\
\mu \mathrm{g} / \mathrm{l}\end{array}$ & $\begin{array}{l}\text { Found } \\
\text { value } \\
\mu \mathrm{g} / 1\end{array}$ & $\begin{array}{l}\text { Recovery } \\
\%\end{array}$ \\
\hline Amersham LEIA & 3.00 & 3.00 & 100 \\
& 1.50 & 1.82 & 121 \\
& 0.75 & 0.92 & 131 \\
& 0.38 & 0.51 & 134 \\
& 0.19 & 0.31 & 163 \\
& 0.09 & 0.18 & 200 \\
& 0 & 0.05 & $/$ \\
& 4.00 & 3.89 & 97 \\
& 2.00 & 1.90 & 95 \\
& 1.00 & 0.93 & 93 \\
& 0.67 & 0.67 & 100 \\
& 0.50 & 0.54 & 108 \\
& 0.33 & 0.37 & 121 \\
& 0.17 & n.d. & $/$ \\
& 0 & n.d. & $/$ \\
\hline
\end{tabular}

Tab. 6b. Standards and control sera measured as unknowns in the contralateral kit.

\begin{tabular}{|c|c|c|}
\hline & $\begin{array}{l}\text { Nominal } \\
\text { concentration } \\
\mu \mathrm{g} / \mathrm{l}\end{array}$ & $\begin{array}{l}\text { Found } \\
\text { concentration } \\
\mu \mathrm{g} / 1\end{array}$ \\
\hline $\begin{array}{l}\text { Amersham LEIA } \\
\text { Abbott Standards }\end{array}$ & $\begin{array}{l}0 \\
4.00 \\
30.0 \\
80.0\end{array}$ & $\begin{array}{l}\text { n.d. } \\
6.32 \\
40.5 \\
\text { over } 60\end{array}$ \\
\hline Abbott control sera & $\begin{array}{c}1.60-3.60 \\
13.8-20.8\end{array}$ & $\begin{array}{c}1.95 \\
16.7\end{array}$ \\
\hline Amersham control sera & $\begin{array}{r}4.00=5.40 \\
10.1=14.3 \\
26.4-36.0\end{array}$ & $\begin{array}{l}4.70 \\
13.2 \\
32.6\end{array}$ \\
\hline $\begin{array}{l}\text { Abbott EIA } \\
\text { Amersham Standards }\end{array}$ & $\begin{array}{l}0 \\
3.00 \\
6 . \\
12.0 \\
25.0 \\
60.0\end{array}$ & $\begin{array}{c}\text { n.d. } \\
2.35 \\
3.54 \\
7.38 \\
18.0 \\
0.46\end{array}$ \\
\hline Abbott control sera & $\begin{array}{c}1.60-3.60 \\
13.8-20.8\end{array}$ & $\begin{array}{l}2.46 \\
18.9\end{array}$ \\
\hline Amersham control sera & $\begin{array}{c}4.00-5.40 \\
10.1-14.3 \\
26.4-36.0\end{array}$ & $\begin{array}{l}4.20 \\
12.2 \\
28.4\end{array}$ \\
\hline
\end{tabular}

Key: $n$. d. - below limit of detection of the assay.

J. Clin. Chem. Clin. Biochem. / Vol. 25, 1987 / No. 10 
Tab. 6c. Dilution of the first standard of the Amerlite kit with a patient serum with no detectable CEA in the Abbott EIA.

\begin{tabular}{rlll}
\hline $\begin{array}{l}\text { Dilution } \\
\text { factor }\end{array}$ & $\begin{array}{l}\text { Expected } \\
\text { concentration } \\
\mu \mathrm{g} / \mathrm{l}\end{array}$ & $\begin{array}{l}\text { Found } \\
\text { concentration } \\
\mu \mathrm{g} / \mathrm{l}\end{array}$ & $\begin{array}{l}\text { Recovery } \\
\%\end{array}$ \\
\hline 1 in 1 & 3.0 & 3.98 & 99 \\
2 & 1.5 & 1.52 & $102(100)$ \\
4 & 0.75 & 0.81 & $108(103)$ \\
8 & 0.38 & 0.43 & $113(103)$ \\
16 & 0.19 & 0.24 & $126(100)$ \\
32 & 0.10 & 0.16 & $160(120)$ \\
64 & 0.05 & 0.12 & $240(160)$ \\
\hline
\end{tabular}

Values are the mean 5 dilution curves performed in duplicate. The values in parentheses are those obtained by correcting the 1 in 2 dilution by $0.04 \mu \mathrm{g} / 1$, i. e. accepting the difference between found and expected values to be correct.

The assay appears to be able to measure correctly down to 0.2 $\mu \mathrm{g} / \mathrm{l}$.

The Abbott kit gave values under $5.0 \mu \mathrm{g} / \mathrm{l}$ for all healthy non-smokers $(n=430)$, and for 640 healthy smokers and non-smokers $98.6 \%$ of all values were under $5.0 \mu \mathrm{g} / 1$. In this study, $98.8 \%$ of the reference group had values under $5.0 \mu \mathrm{g} / \mathrm{l}$ with the Abbott kit.
The sensitivity of the Amerlite kit was given as "better than $0.5 \mu \mathrm{g} / \mathrm{l}$ ", that for the Abbott kit as "calculated to be approximately $0.5 \mu \mathrm{g} / \mathrm{l}$ ". The results of this study confirm the Abbott results and support the Amersham claims (see tab. 6a \& 6c).

Table $6 \mathrm{~b}$ demonstrates once again, that kit standards, even though calibrated against the same international reference material (here WHO 73/601), are not interchangeable. This is shown most dramatically for the highest Amersham standard $(60 \mu \mathrm{g} / \mathrm{l})$ which gave a value of less than $0.5 \mu \mathrm{g} / 1$ when measured as sample in the Abbott kit. This value was repeatedly obtained, and so a mistake in the measurement itself can be excluded. The question of a high dose hook effect can be ruled out as sera with CEA levels above 1500 $\mu \mathrm{g} / \mathrm{l}$ still gave an optical density reading in the Abbott kit above that of the highest standard $(80 \mu \mathrm{g} / \mathrm{l})$.

To conclude, it can be shown that both kits are similar in performance, and that the luminescence enhanced enzyme immunoassay kit from Amersham International can take its place alongside other established non-radioisotopic methods. However, like its competitors, the luninescence enhanced enzyme immunoassay cannot be used as a "screening method", but only in the follow-up and control of tumour patients.

\section{References}

1. Arakawa, H., Maeda, M. \& Tsuji, A. (1976) Bunsaki Kagaku $26,322-326$.

2. Wood, W. G., Bellinger, H., Schulz, E. \& Otte, M. (1984) Ärzt. Lab. 30, 105-114.

3. Wood, W. G., Hantke, U. \& Gross, A. J. (1985) J. Clin. Chem. Clin. Biochem. 23, 47-49.

4. Brolin, S. E., Borglund, E., Tegner, L. \& Wettermark, G. (1971) Anal. Biochem. 42, 124-135.

5. Thorpe, G. H. G., Gillespie, E., Haggart, R., Kricka, L. J. \& Whitehead, T. P. (1984) In: Analytical Applications of Bioluminescence and Chemiluminescence (Kricka, L. J., Stanley, P. E., Thorpe, G. H. G., Whitehead, T. P., eds.) Academic Press, London, Orlando, pp. 243-248.

6. Wood, W. G. (1985) In: Immunoassay Technology, Vol. 1 (Pal, S. B., ed.) de Gruyter, Berlin-New York, pp. 105130.

7. Masseyeff, R. \& Krebs, B. (1985) In: Tumor Marker Antigens - Properties and usefulness of carcinoma associated antigens CEA, CA 19-9 and CA 50 (Holmgren, J., ed.) Studentlitteratur, Lund, pp. 80-93.

Priv.-Doz. Dr. W. G. Wood

Klinische Laboratorien

Klinik für Innere Medizin

Medizinische Universität zu Lübeck

Ratzeburger Allee 160

D-2400 Lübeck 1 
